\title{
Czy można zaprojektować kreatywność pracownika? Refleksje nad relacjami designu i zarządzania
}

\begin{abstract}
Innovation of products is one of the most important factor of competition therefore supporting of creative actions of employers is one of the intentionally introduced changes in the organization. Historical analysis of development of management theories from one hand and projects of organization of work spaces form the other hand show co-evolution of them. That is main changes of management theories join with changes in design. In this paper we try to identify (using projects from web sites and specialist publication) a few trends relating to create work space supporting creativity. One of the important trends is imitation of the solutions implemented by companies that are considered innovative. Therefor you wonder if spatial solutions support changes in management practices or rather replace them. In other words, if in some cases the management is not replaced by the design.
\end{abstract}

\section{Keywords:}

designing of work space, creativity, relations between human management and design

1 Anita Basińska, Katedra Wzornictwa (School of Form), SWPS Uniwersytet Humanistycznospołeczny, Wydział Zamiejscowy w Poznaniu, Polska, abasinska@sof.edu.pl.

${ }^{2}$ Agnieszka Jeran, Instytut Socjologii, Wydział Nauk Społecznych, Uniwersytet im. Adama Mickiewicza w Poznaniu, Polska, a.jeran@wp.pl. 


\section{WPROWADZENIE}

Celem artykułu jest wskazanie sposobów, w jakie przedsiębiorstwa (pracodawcy) poprzez kształtowanie miejsca pracy (w sensie przestrzennym, jego wyposażenia i organizacji) odpowiadają na wyzwania związane z innowacyjnością wytwarzanych produktów i usług. W ostatecznym rozrachunku innowacyjność oferty przedsiębiorstwa zależy od kreatywności jego pracowników. Znaczenie przemysłów kreatywnych, diagnozowanie powstania klasy kreatywnej czy też traktowanie innowacyjności jako podstawowej składowej przewagi konkurencyjnej skłania podmioty gospodarcze do podejmowania działań wspierających (najogólniej mówiąc) kreatywność pracowników. W niniejszej analizie ograniczamy się do rozpatrywania fizycznego wymiaru miejsca pracy, pamiętając jednak o tym, że organizacja przestrzeni, wyposażenie itp., czyli cały design miejsca pracy, jest jednym z kluczowych czynników determinujących typ i efekty aktywności w miejscu pracy, jednak nie jedynym i prawdopodobnie nie najważniejszym. Pracodawca przekształcając przestrzeń pracy może kierować się wskazaniami psychologów, socjologów czy specjalistów od ergonomii, może zdać się na modę i wskazania producentów np. mebli biurowych, może też oddać decyzje projektantom czy wreszcie po prostu zdecydować się na naśladowanie podmiotów, których rozwiązania projektowe zdają się wprost stymulować kreatywność pracowników, a przynajmniej są jako takie ukazywane (np. w specjalistycznych przekazach, skierowanych do projektantów lub praktyków zarządzania). W zakresie przedmiotowym przegląd ten został ograniczony do projektów dotyczących przestrzeni biurowych.

Przesłanką analizowania związków pomiędzy projektowaniem przestrzeni (designem) a zarządzaniem ludźmi i ich pracą jest przede wszystkim konstatacja, że stosunkowo wyraźnie można prześledzić wzajemne związki pomiędzy kolejnymi wyłaniającymi się z refleksji nad organizacjami wytycznymi w zakresie zarządzania a przekształceniami miejsc pracy. W niniejszej analizie związki te rozpatrujemy ograniczając się do perspektywy pracy „biurowej”, szczególnie więc odnoszącej się do aktywności pracowników związanej z przetwarzaniem, tworzeniem i dystrybucją informacji, czyli do pracy umysłowej o różnym poziomie skomplikowania: od prostej pracy rutynowej do twórczej, wymagającej dużego zaangażowania. W ramach wspomnianej długiej tradycji wiążącej metody i cele zarządzania zasobami - w tym ludźmi - z kształtowaniem miejsca pracy w całej jego namacalnej fizyczności, coraz intensywniej zachodzą procesy celowego kształtowania przestrzeni pracy, która sprzyjać ma właśnie kreatywności. Dlatego wychodząc od warunków, jakie kreatywności sprzyjają, chcemy prześledzić projekty i proponowane rozwiązania, zastanawiając się nad trafnością wdrożonych 
rozwiązań. Bardzo istotne pytanie w kontekście relacji projektowania i zarządzania dotyczy tego, czy pierwotny związek, w którym odpowiedzią na nowe rozwiązania zarządcze były nowe sposoby organizowania przestrzeni pracy, nie przekształcił się $\mathrm{w}$ trend zastępowania zmian organizacyjnych, tj. zmian w zarządzaniu, zmianami projektowymi.

\section{ORGANIZACJA I PRZESTRZEŃ}

Historycznie zorientowana analiza przekształcania się miejsc pracy i teorii organizacji i zarządzania pozwala wskazać, że - przynajmniej w odniesieniu do miejsc pracy umysłowej, ogólnie rozumianego „biura” - wyraźna jest swego rodzaju koewolucja obu obszarów. W miarę jak akceptację uzyskiwały kolejne nurty teorii i wyłaniających się z nich praktycznych wskazówek na polu organizacji i zarządzania, przekształceniu ulegały także miejsca pracy w swoim fizycznym wymiarze, tj. organizacji przestrzeni, wyposażenia itd.

Jednym ze sposobów ujęcia tej relacji jest wskazanie, że przestrzenie biurowe zmieniały się cyklicznie wg opozycji: otwartość vs prywatność, interakcje vs autonomia (Kuang 2009). W historii projektów możemy więc wskazać:

- Taylorowskie biuro łączące otwartą przestrzeń dla pracowników i prywatne biura dla kierownictwa;

- Bürolandschaft, czyli otwartą przestrzeń i nacisk na interakcje między pracownikami;

- Action Office oparty na systemie mebli zapewniających w zależności od potrzeb interakcje lub autonomię oraz względną prywatność;

- Cube Farm, czyli przestrzeń ekstremalnie zamknięta do małych pudełek, kładąca nacisk na prywatność, nie interakcje;

- Biuro wirtualne - otwarta przestrzeń, bez biurek;

- Networking - szukanie balansu pomiędzy otwartością i prywatnością, interakcjami i autonomią.

Z kolei Dzidowski (2015, s. 158) te same procesy ujmuje następująco: „przestrzeń organizacyjna (terytorium) ewoluowała wraz z koncepcjami Taylorowskiego naukowego zarządzania, przez socjaldemokratyczny Bürolandschaft, adaptacyjno-efektywnościowe Action Office i wynaturzone Farmy Kubików, aż po przestrzenie otwarte, czy wręcz nieformalne, co odzwierciedlało zmieniające się podstawy kultury organizacyjnej oraz zmienną istotę pracy biurowej”.

Co interesujące, chociaż relacje między przestrzenią a zachowaniami ludzi są przedmiotem namysłu zarówno przedstawicieli nauk zajmujących się przestrzenią 
(urbanistów, architektów), jak i zachowaniami ludzi (socjologów, psychologów), to szczególnie w przypadku socjologów wyraźniejszy w nich jest trop kształtowania przestrzeni miejskich (np. socjologia miasta i jej różne podejścia, z rewitalizacją społeczną włącznie).

\section{KREATYWNOŚĆ}

Praca ulega przekształceniom wraz z rozwojem nowych technologii, produktów i usług, ale i samych kompetencji pracowników. Współcześnie coraz częściej wskazuje się na rosnące znaczenie pracy kreatywnej, zespołowej czy projektowej, w elastycznych i dynamicznie zmieniających się zespołach. Działania rutynowe, powtarzalne, możliwe do objęcia algorytmami postępowania maszynowego (komputerowego), coraz częściej przekazywane są komputerom i robotom, podczas gdy (choć to dopiero raczej wizja niż rzeczywistość) ludzkiemu pracownikowi pozostawia się wszystko to, co nierutynowe - albo ze względu na wymaganą kreatywność, albo ze względu na niezbędne wchodzenie w relacje społeczne (usługi). Szczególnie interesujące są w tym zakresie wskazania (jako odrębnego i kluczowego dla rozwoju gospodarczego) podsystemu przemysłów kreatywnych, a w strukturze społecznej - klasy kreatywnej - pracowników, których głównym zadaniem jest praca kreatywna (Florida, 2003). Mają oni stanowić nawet 30\% pracowników w USA (Chan, Beckman, Lawrence, 2007, s. 6).

Kluczowe w odniesieniu do kreatywności pracowników (czy też samego jej postulowania) jest przekształcenie naukowego myślenia o kreatywności z uznawania jej za cechę szczególną wyjątkowej grupy ludzi do poglądu, że jest jedną z powszechnych kompetencji, możliwych do wspierania i rozwoju (Lipowska, 2013; Purc i in., 2015). Uznanie, że „każdy może być kreatywny” sprawia, że możliwe staje się myślenie w ten sposób o każdym pracowniku, choć oczywiście poziom tej kreatywności jest zróżnicowany, co wynika zarówno z wewnętrznych cech jednostki (jak przebieg procesów poznawczych czy osobowość), jak i oddziaływania otoczenia i interakcji jednostki ze środowiskiem (w tym - środowiskiem pracy - Lipowska, 2013). W odniesieniu do środowiska, a więc miejsca pracy, wskazuje się na takie czynniki jak klimat organizacyjny, nastawienie na innowacyjność, zasoby umożliwiające zachowania kreatywne (w tym - szkolenia czy czas) oraz wspierające kreatywność zachowania zarządcze (dostarczanie wyzwań, wspieranie autonomii czy budowanie zespołu) (Lipowska, 2013, s. 25). Ujęcia (Purc i in. 2015; Törnqvist, 1983, za: Przygodzki, 2013), akcentujące współwystępowanie i wzajemne oddziaływanie czynników obejmujących łącznie cechy wewnętrzne 
pracownika, charakter zadań zawodowych i praktyki zarządcze, pozwalają na formułowanie wytycznych w odniesieniu do pracodawcy i kształtowania przez niego takiego środowiska pracy, które tworzyłoby warunki wspierające kreatywność pracowników. Nie jest z pewnością zaskoczeniem, że są to przede wszystkim czynniki o charakterze społecznym i psychologicznym (Purc i in, 2015), takie jak:

- wysoka złożoność wykonywanych zadań, ich różnorodność oraz autonomia w ich realizacji;

- dostępność zasobów materialnych, czasu i wiedzy;

- kontakty z innymi pracownikami, wymiana pomysłów i praca zespołowa, możliwość kontaktowania się z ekspertami;

- adekwatna i udzielana na bieżąco informacja zwrotna ze strony przełożonego.

W odniesieniu do pracy zespołowej warto zauważyć, że z jednej strony jest to tylko jeden z wielu sposobów generowania pomysłów (szczególnie jako tzw. „burza mózgów”), z drugiej zaś, że jako proces grupowy może przebiegać na wiele sposób, nie zawsze sprzyjających wypracowywaniu rozwiązań innowacyjnych (por. Lipowska, 2013, s. 27), choć niewątpliwie jednym z kluczowych czynników kreatywności są kontakty społeczne. Jednak dopracowanie pomysłu, przemyślenie jego implikacji wymaga niejednokrotnie właśnie oderwania się od grupy i pracy indywidualnej, ponieważ wymaga skupienia. Komunikacja i dialog sprzyjające generowaniu pomysłów, ich testowaniu i modyfikowaniu (por. Kampka, 2008), powinny więc być przeplatane z okresami pracy samodzielnej. Ten schemat zresztą pozwala wyjaśnić jeden z nieco zaskakujących wyników badań - z sondażu Gallupa („State of the Global Workplace”) wynika, że tylko 10\% pracowników na świecie przebywając w biurze czuje się zainspirowanymi, zaś 2/3 w tym samym środowisku skarży się na brak motywacji. Najbardziej zaangażowani są ci, którzy około 1/5 czasu pracy spędzają poza biurem (Bulska, 2016). Można sądzić, że spędzając czas poza miejscem pracy pracownicy ci korzystają z warunków umożliwiających samodzielną pracę.

\section{MIEJSCE PRACY SPRZYJAJĄCE KREATYWNOŚCI}

Jeśli zatem kreatywność można niejako wywoływać i wspierać poprzez odpowiednie działania współpracowników i przełożonych, a w organizacji kształtować klimat sprzyjający kreatywności, to można także w sensie fizycznym zaprojektować miejsce pracy, które chociażby wspiera spotkania i dialog, dostarcza różnorodnych bodźców, pozwala na regenerację fizyczną i psychiczną pracowników czy 
na (istotną dla poczucia kontroli i autonomii) samodzielność pracownika w jego organizowaniu.

Wzrost znaczenia innowacyjności w gospodarce i jednocześnie pojawienie się przedsiębiorstw stawianych jako wzór innowacyjności, odnoszących globalny sukces dzięki kreatywności swoich pracowników, sprawiają, że pojawiła się moda na kształtowanie organizacji wg ich modelu. Ponieważ znacznie trudniej przekształcić kulturę organizacji i praktyki zarządcze, niejednokrotnie pierwszym (a często jedynym) krokiem jest zaprojektowanie miejsca pracy zgodnie z jednym ze zidentyfikowanych i skopiowanych trendów. Szczególnym przykładem może być trend określany jako „googliness” czyli kopiowanie stylu i warunków pracy w Google (Wojtaszczyk, 2013, s. 256). Co interesujące, nawet jeśli nie jest to wprost kopiowanie, tylko oparcie na jakiejś bardziej złożonej ideologii, działanie sprowadza się do przeprojektowania przestrzeni, a znaczenie kultury organizacyjnej bywa obecne tylko w uzasadnieniu konkretnego projektowego rozwiązania - przykładem może być opis założenia „Activity Based Working” (opracowanego przez holenderskie biuro Veldhoen \& Company), które odnosi się wprost do artykułu naukowego z lat 80. XX w., dotyczącego takiego projektowania biura, aby możliwe było realizowanie różnych potrzeb pracowników w ciągu dnia pracy (Stone, Luchetti, 1985, za: Savege, 2005). W tej koncepcji punktem wyjścia dla projektu jest wskazanie, że „to sami pracownicy najlepiej wiedzą, czego w danym momencie im potrzeba”. Chociaż nie ma chodzić o prostą stylizację, to jednak sprowadza się często właśnie do niej, lub do przekształcania przestrzeni biura tak, by spełniała jedno z wybranych założeń, np. była komfortowa akustycznie czy pozwalała na odseparowanie od otoczenia (Nie biurko i nie open space, 2016).

Można sądzić, że w pewnym sensie działania te nie tyle włączają design w zmiany kultury organizacji, co zastępują zmiany kultury, praktyk zarządczych i systemów motywacyjnych zmianą przestrzenną.

\section{REALIZACJE - PRZYKŁADY W ZAŁOŻENIU KREATYWNYCH MIEJSC PRACY}

Poniżej przedstawiamy wyniki przeglądu zdjęć biur i ich opisów ze stron internetowych z obszaru projektowania (np. sztukawnetrza) oraz stron konkretnych biur projektowych i przedsiębiorstw. Początkowo naszym zamiarem było poddanie analizie kilku wybranych biur, takich jak biuro Googla czy Youtube, jednakże po przejrzeniu kilkudziesięciu projektów biur wydaje się, że wskazanie pewnych trendów w kształtowaniu biur, które - w założeniu projektantów - mają stymulować 
kreatywność i gwarantować wzrost efektywności, jest ciekawszym poznawczo podejściem, szczególnie na etapie eksploracyjnym. W przedstawionym przeglądzie identyfikujemy następujące trendy w zakresie organizacji przestrzeni pracy biurowej: wielofunkcyjność, tematyczność, work \& play oraz eklektyzm.

\section{Wielofunkcyjność przestrzeni}

Ważną charakterystyką współczesnych biur są przeobrażenia otwartej przestrzeni. Badania pokazały, że otwarte przestrzenie generowały zbyt dużo hałasu, co utrudniało pracę, wywoływało stres i frustrację (Green, 2013). W efekcie obok otwartych przestrzeni pojawiły się przestrzenie do pracy indywidualnej, tzw. lounge - „wyposażone są w miękkie, przytulne meble, które mają sprzyjać budowaniu mniej formalnej atmosfery i bardziej kreatywnej atmosferze. Według psychologów biznesu, takie rozwiązania sprzyjają innowacyjnym pomysłom i wzmacniają komunikację w zespole” (Jak zaprojektować biuro. Mniej open space? 2015).

Z kolei zgodnie z koncepcją Activity Based Working pracownicy mogą pracować jak i gdzie chcą, dlatego też coraz częściej przestrzeń biurowa dzielona jest na różne strefy dedykowane konkretnym czynnościom: relaksowi (tzw. fun room, escape room, chill out room), pracy zespołowej, nieformalnym rozmowom, pracy indywidualnej i wyciszeniu (podobnie jak w XVII w., gdy pojawiło się zacisze w domu - pomieszczenie, w którym człowiek mógł w spokoju i samotnie pracować (Rybczyński, 2015)). Przestrzeń biurowa ma być więc elastyczna i wielofunkcyjna, ponieważ „firma oferująca pracownikom autonomię i wybór rozwija się cztery razy szybciej niż firmy, które tego nie robią” (Akitunde, 2014). Powszechne staje się nie tylko projektowanie miejsc pracy, ale i rekreacji, a nawet miejsc do spania (Bulska, 2016).

\section{Tematyczność}

Podobnie jak w obrębie organizacji czasu wolnego pojawiły się wioski tematyczne, tematyczne parki rozrywki czy centra handlowe (niektóre hotele czy pensjonaty oferują pokoje tematyczne), tak i w biurach pojawiają się pomieszczenia tematyczne, które wystrojem wnętrza, meblami mają przypominać np. morze (krzesła odwołujące się kolorem i materiałem do bursztynu), podróże (wstęga na podłodze ma obrazować rzekę, żółte fale na ścianie - pustynię) czy salon w domu (miękkie sofy, ławy do kawy, dywany). W opisie jednego z biur możemy więc przeczytać: „Motywami przewodnimi są polskie krajobrazy: las, morze, plaża; bogactwa naturalne: węgiel, sól, bursztyn; elementy folklorystyczne - jak polska koronka, a także sławni Polacy” (Największe europejskie biuro JLL, 2016). 


\section{Work \& Play}

Trend work \& play w projektowaniu przestrzeni do pracy wiąże się m.in. z wprowadzeniem do przestrzeni pracy, obok biurek czy stołów do pracy i krzeseł, przedmiotów związanych z relaksem biernym lub czynnym - takich jak sofy, hamaki, huśtawki, zjeżdżalnie, gry planszowe czy stoły do ping-ponga. Ten trend widoczny jest także w wydzielaniu w biurze pomieszczeń dedykowanych aktywnościom jednoznacznie dotychczas zarezerwowanym dla czasu nie-pracy - są to siłownie, kawiarnie, miejsca z konsolami do gier komputerowych czy do gry na instrumentach. Projektanci i producenci mebli proponują wprost systemy meblowe typu play \& work (Czy praca w biurze może być przyjemna?, 2015).

\section{Eklektyzm}

Przez długi czas wnętrza biur pozostawały minimalistyczne i tendencja ta nadal jest obecna, chociaż istnieją badania wskazujące na niekorzystne dla efektywności oddziaływanie nadmiernego minimalizowania wyposażenia przestrzeni biura, czy to pod względem kolorystyki, czy ilości elementów.

Eklektyzm jest swoistym odwróceniem tego minimalistycznego trendu. Ściany stają się kolorowe, podobnie jak pozostałe elementy wyposażenia - lampy, kaloryfery, rury, doniczki, lustra itd. Oprócz żywych kolorów, na ścianach pojawia się graffiti, zdjęcia, obrazki, wzorzyste płytki. Także podłogi się zmieniają: w zależności od projektu mogą być kolorowe, drewniane, pokryte dywanami czy orientalnymi płytkami. Jak takie wnętrze reklamują ich projektanci?: „Urocze, perskie dywaniki oraz rośliny doniczkowe sprawiają, że zaciera się granica między przestrzenią domową, a biurową. Dzięki białym ścianom i lustrom wnętrze wydaje się większe, niż w rzeczywistości” (Bazarowy wdzięk, 2016, s. 7). Z kolei wielofunkcyjne, lekkie meble mają pozwalać na dopasowywanie miejsca pracy do aktualnych potrzeb. Przed meblami stają poważne zadania - mają być „kolorowe, wesołe, ciekawe, zaskakujące” (Jak zaprojektować..., 2015).

\section{CZY DESIGN MOŻE ZASTĄPIĆ ZARZĄDZANIE?}

Można sądzić, że część postulatów dotyczących przekształcania miejsc pracy w taki sposób, by sprzyjały kreatywności, może i powinna znajdować swoje odzwierciedlenie w samym projekcie miejsca. Jeśli uwzględnić wagę umożliwienia pracownikom zarówno spotkań i komunikacji, tak zorganizowanych, jak i spontanicznych z jednej strony, zaś warunków do spokojnej, skupionej, indywidualnej pracy z drugiej, to zaprojektowanie tego w sensie fizycznym wydaje się 
trafną strategią. Jednak już sprzęty czy przestrzenie służące rekreacji budzą więcej wątpliwości, podobnie jak wprowadzanie eklektyczności czy tematyczności. Wszak badania poświęcone skupianiu uwagi wskazują, że nadmiar bodźców jest niekorzystny (Klein, 2009). Podobnie badania nad kreatywnością wskazują, że dla jej utrzymywania niezbędna jest wielość doświadczeń i otwartość, której nie zastąpi nieustanne pozostawanie w pracy (Przygodzki, 2013). Tymczasem trend work \& play czy też rozbudowywanie funkcji rekreacyjnych budzą wątpliwości związane z tym, czy faktycznie zabiegi te służą uprzyjemnianiu pracy, czy raczej takiemu zakotwiczeniu w niej pracownika, by nie chciał z pracy wychodzić, skoro „Googlersi nie zabierają zatem pracy do domu - oni przynoszą dom do miejsca zatrudnienia. Nie tylko bowiem sami aranżują swoje stanowiska pracy, ale przychodzą do pracy z dziećmi i zwierzętami oraz zapraszają do firmy znajomych” (Wojtaszczyk, 2013, s. 255). Osobną kwestię stanowi adekwatność takich rozwiązań - prawdopodobnie hamaki czy strefy gier nie będą interesujące, gdy pracownicy się zestarzeją (Dzidowski, 2015, s. 66), podobnie jak dla obecnie starszych takie miejsce pracy już teraz może być trudne do zaakceptowania. To podejście infantylizuje pracowników, a do wielu organizacji po prostu nie pasuje (Play \& Work to katastrofa?, 2016, s. 10).

Niewątpliwie każde z wprowadzanych rozwiązań projektowych ma swoje wady i zalety (por. Wojtaszczyk, 2013), jednak w sytuacji, w której nie uwzględnia się specyfiki organizacji, a przeprojektowaniem przestrzeni zastępuje takie niezbędne zmiany w zarządzaniu jak zwiększanie autonomii, wprowadzanie zróżnicowanych zadań, poprawa efektywności komunikacji zwrotnej czy zwiększanie dostępu do zasobów, wydaje się ono nie mieć żadnych zalet. Niewątpliwie dla części pracowników możliwość pochwalenia się pracą w biurze w stylu google będzie miała znaczenie wizerunkowe i motywacyjne, czy jednak trwale i efektywnie przełoży się na wzrost kreatywności?

\section{Literatura:}

Akitunde, A. (2014). Open Office Backlash: Seeing Productivity in a Noisy World. Pobrane z: https://www.americanexpress.com/us/small-business/openforum/articles/ open-office-backlash-seeking-productivity-in-a-noisy-world/ [2016.11.10].

Bulska, D. (2016). Praca w biurach przyszłości. Pobrane z: http://www.brief.pl/artyku1,3930,praca_w_biurach_przyszlosci.html [2016.11.10].

Chan, J., Beckman, S., Lawrence, P.G. (2007). Workplace Design: A New Managerial Imperative. California Review Management, 355, 2/01/07.

Dzidowski, A. (2015). Architektura organizacyjna. Pomiędzy strukturą a przestrzenią organizacji. Przegląd Lubuski, 41, część 1. 
Florida, R. (2003). Cities and the Creative Class, American Sociological Association. Pobrane z: http://creativeclass.com/rfcgdb/articles/4\%20Cities\%20and\%20the\%20 Creative\%20Class.pdf [2016.11.10].

Green, S.C. (2013). Research: Cubicles Are the Absolute Worst. Harvard Business Review, 11. Pobrane z: https://hbr.org/2013/11/research-cubicles-are-the-absolute-worst [2016.11.10].

Kampka, F. (2008). Kreatywność w przedsiębiorstwie - pomiędzy jednostką a zespołem. W: K. Krzyżanowska (red.), Komunikowanie w działalności przedsiębiorczej. Warszawa: Wydawnictwo SGGW.

Klein, S. (2009). Czas. Przewodnik użytkownika. Warszawa: Wydawnictwo W.A.B.

Kuang, C. (2009). Evolution of Office Spaces Reflects Changing Attitudes Toward Work. Wired, 3. Pobrane z: https://www.wired.com/2009/03/pl-design-5/.

Lipowska, J. (2013). Zależność kreatywności pracowników od elementów środowiska pracy. Zarządzanie Zasobami Ludzkimi, 1.

Play \& Work to katastrofa? 2016, Krytyka Architektury, 1-2.

Przygodzki, Z. (2013). Kreatywność i zdolności innowacyjne kapitału ludzkiego, w kontekście warunków kształtowania jakości otoczenia lokalnego. Acta Universitatis Lodziensis, Folia Oeconomica, 290.

Purc, E., Wałachowska, K., Żaliński, A., Mielniczuk, E., Patynowska, E., Łaguna, M. (2015). Innowacja w organizacji: Sposoby ujmowania i przegląd uwarunkowań. Zagadnienia Naukoznawstwa, 4 (206).

Rybczyński, W. (2015). Dom. Krótka historia idei. Kraków: Wydawnictwo Karakter.

Savege, A.E. (2005). Workplace strategy: What it is and why you should care. Journal of Corporate Real Estate, Vol. 7, No. 3.

Stone, Ph.J., Luchetti, R. (1985). Your office is where you are. Harvard Business Review, March-April 1985, Volume 63, Number 2.

Wojtaszczyk, K. (2013). (Dys)funkcjonalne rozwiązania w zakresie kształtowania warunków pracy przykład firmy Google. Acta Universitatis Lodziensis, Folia Oeconomica, 288.

\section{Materiał źródłowy:}

Bazarowy wdzięk (2016). Pobrane z: http://www.sztuka-wnetrza.pl/4553/slajdy/bazarowy-wdziek-strona-7 [2016.11.10].

Czy praca w biurze może być przyjemna? (2015) Pobrane z: http://archinea.pl/wnetrzabiurowe-system-meblowy-playwork-grupy-nowy-styl/ [2016.11.20].

Jak zaprojektować biuro. Mniej open space? (2015) Pobrane z: http://www.sztuka-wnetrza. pl/1698/artykul/jak-zaprojektowac-biuro-mniej-open-space [2016.11.10].

Największe europejskie biuro JLL (2016) Pobrane z: http://www.sztuka-wnetrza.pl/4663/ artykul/najwieksze-europejskie-biuro-jll [2016.11.10].

Nie biurko i nie open space (2016) Pobrane z: http://www.propertydesign.pl/design/185/ nie_biurko_i_nie_open_space_czyli_projektowanie_biura_xxi_wieku,8546.html [2016.11.20]. 